\title{
A Microethnographic and Ethnobotanical Approach to Llayta Consumption among Andes Feeding Practices
}

\author{
Mailing Rivera ${ }^{1}$, Alexandra Galetović ${ }^{2}$, Romina Licuime ${ }^{1}$ and Benito Gómez-Silva ${ }^{2, *(D)}$ \\ 1 Departamento de Educación, Facultad de Educación, Universidad de Antofagasta, \\ Antofagasta 124000, Chile; mailing.rivera@uantof.cl (M.R.); rlicuime1505@gmail.com (R.L.) \\ 2 Departamento Biomédico, Facultad Ciencias de la Salud, and Centre for Biotechnology and Bioengineering, \\ CeBiB, Universidad de Antofagasta; Antofagasta 1240000, Chile; alexandra.galetovic@uantof.cl \\ * Correspondence: benito.gomez@uantof.cl; Tel.: +56-9-98297844
}

Received: 29 October 2018; Accepted: 28 November 2018; Published: 9 December 2018

\begin{abstract}
Llayta is a dietary supplement that has been used by rural communities in Perú and northern Chile since pre-Columbian days. Llayta is the biomass of colonies of a Nostoc cyanobacterium grown in wetlands of the Andean highlands, harvested, sun-dried and sold as an ingredient for human consumption. The biomass has a substantial content of essential amino acids ( $58 \%$ of total amino acids) and polyunsaturated fatty acids (33\% total fatty acids). This ancestral practice is being lost and the causes were investigated by an ethnographic approach to register the social representations of Llayta, to document how this Andean feeding practice is perceived and how much the community knows about Llayta. Only $37 \%$ of the participants (mostly adults) have had a direct experience with Llayta; other participants (mostly children) did not have any knowledge about it. These social responses reflect anthropological and cultural tensions associated with a lack of knowledge on Andean algae, sites where to find Llayta, where it is commercialized, how it is cooked and on its nutritional benefits. The loss of this ancestral feeding practice, mostly in northern Chile, is probably associated with cultural changes, migration of the rural communities, and very limited access to the available information. We propose that Llayta consumption can be revitalized by developing appropriate educational strategies and investigating potential new food derivatives based on the biomass from the isolated Llayta cyanobacterium.
\end{abstract}

Keywords: Andean microalgae consumption; Atacama; cyanobacteria; Llayta; microethnography; Nostoc

\section{Introduction}

The abundance and diversity of organisms in the Atacama Desert are severely limited by the high levels of desiccation and ultraviolet light [1,2]. In the Andes Mountains highlands, biodiversity is higher and plants have been used for centuries by local communities for feeding, foraging and ethnomedicine [3-8]. Microalgae and cyanobacteria are part of the Andes biodiversity but seldom acknowledged. Based on their nutritional and digestive benefits, microalgae and cyanobacteria (i.e., Chlorella, Dunaliella, Arthrospira and Nostoc) have been part of the human diet in South America, North America, Asia and Africa. Also, some species are natural resources for a variety of organic molecules with high interest to the biotechnological industry (proteins, amino acids, vitamins, polyunsaturated fatty acids, pigments) $[3,4,9,10]$. Edible members of the Nostoc genus are found in China where Nostoc flagelliforme has been consumed as a delicacy for centuries but its collection is prohibited today due to over-exploitation [11,12]. In South America, an indigenous foodstuff harvested in the Andes wetlands, known as Llayta, is the dry biomass of macrocolonies of a cyanobacterium from 
the genus Nostoc (Figure 1). Llayta consumption is a practice that can be traced back to pre-Columbian times and it has been recorded in documents from the 17th century $[13,14]$ and, in a more recent botanical report [15].

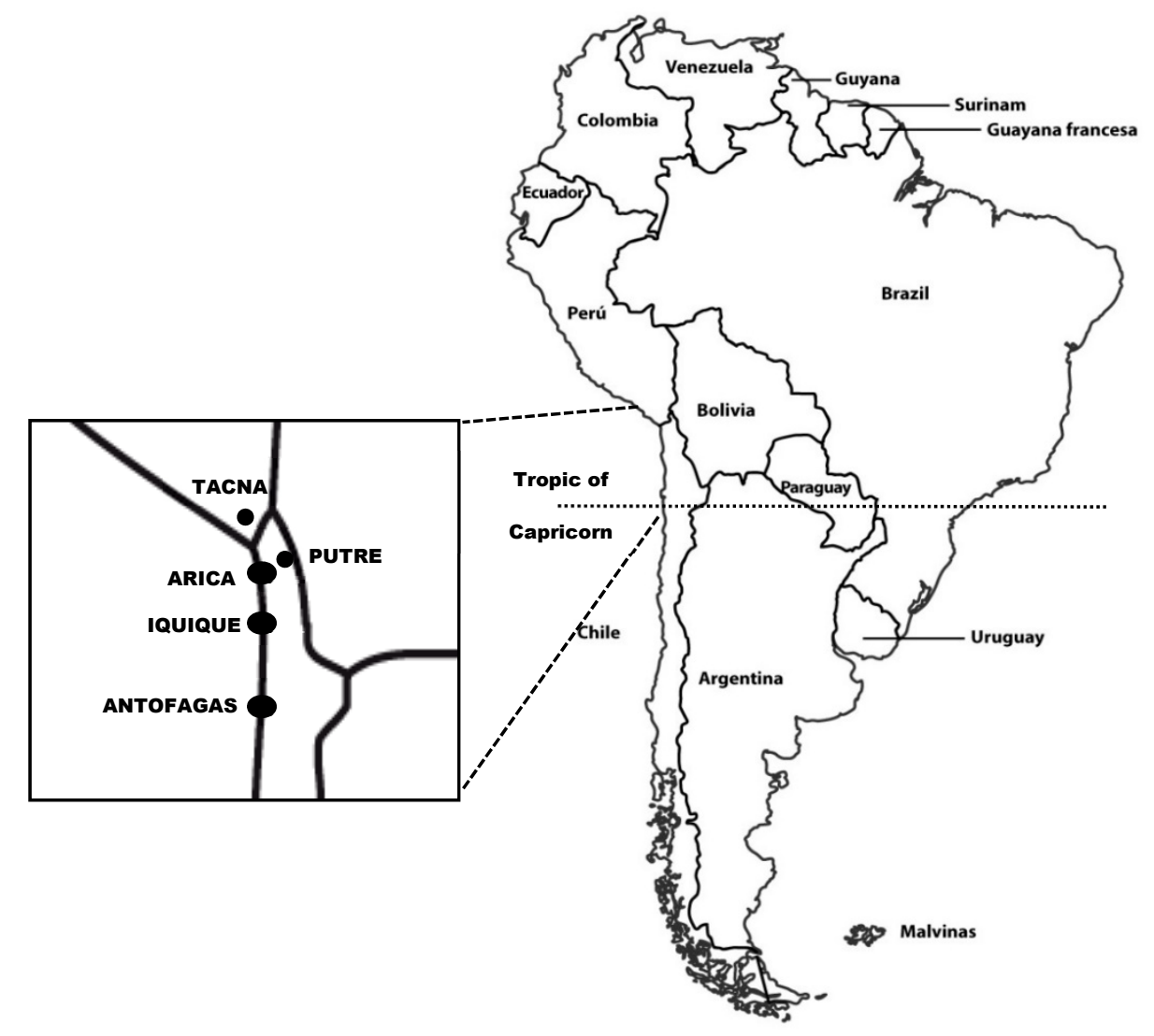

Figure 1. Locations, in southern Peru and northern Chile, where information on Llayta was acquired.

Thus, the genus Nostoc has been an old component of the human diet in South America, and it continues to be used today as a food additive in northern Chile (Arica y Parinacota and Tarapacá Regions) and in southern Peru (Tacna City) (Figure 2) [5,6,8,16-18]. However, and based on preliminary interviews, this ancient culinary legacy is disappearing and it is already unknown by the urban communities from other areas of the region; for example, at Antofagasta, the major coastal city in northern Chile, nearly $400 \mathrm{~km}$ south of Iquique (Figure 2).

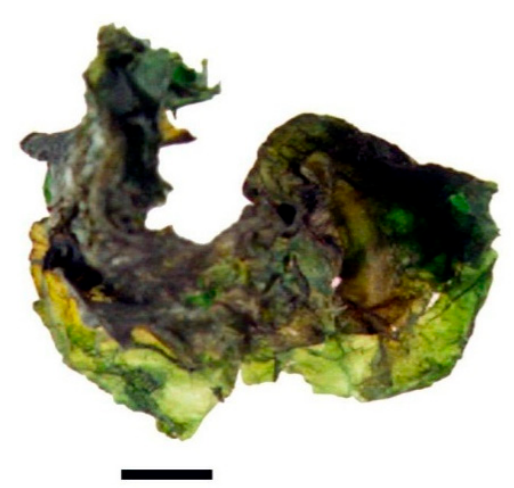

Figure 2. A dry colony of Llayta obtained at a major food market in Arica, Chile. (Bar: $1 \mathrm{~cm})$.

Our report provides the results of a microethnographic study conducted to learn how much people know about Llayta and their perception on this ancestral Andean ingredient, and is meant to 
be complementary to biochemical studies done on Llayta [4]. This work was based on the following considerations: (i) Llayta consumption is a feeding practice transmitted through generations in the rural Andean world of South America, without reports of adverse effects on human health; (ii) Llayta consumption is an old culinary legacy that is disappearing in regions of South America; (iii) Llayta is a nutritional ingredient containing essential amino acids (58\% of total amino acids) and polyunsaturated fatty acids (33\% total fatty acids); (iv) the prevalence of undernourishment in South America; (iv) Llayta consumption can be revitalized with appropriate educational strategies and new food derivatives can be developed from the biomass of the isolated cyanobacterium from Llayta $[4,9,18,19]$.

We propose that this microethnographic approach will help us to explore explanations for an apparent decrease in Llayta consumption, and to provide arguments and suggestions for the revitalization of this feeding practice.

\section{Materials and Methods}

\subsection{The Microethnographic Study}

The microethnographic study on Llayta was designed to learn about the direct or indirect knowledge people have about Llayta by collecting social representations [20] from interviewing participants, including drawings prepared by children. The main expressions about Llayta were ethnographically registered and analyzed in order to explain the social worlds built by persons about their understanding of the surrounding natural, social and cultural environment [21].

\subsection{Sample for the Microethnographic Study}

Observations were carried out during the first half of 2014 in Tacna (Peru) and Putre (Chile) (Figure 2). Tacna is a Peruvian city located at the frontier between Peru and Chile with an active commercial exchange with Arica and Iquique, two coastal cities in Chile. Putre is a rural village at $2500 \mathrm{~m}$ above sea level in the Andes Range in northern Chile, close to sites where Llayta is harvested.

The participants were 19 active members of their community who were informed about the origin and purpose of the study. Their selection was based on their willingness to participate anonymously in the interviews.

The participants were 12 fourth-grade students ( 7 boys and 5 girls, 9-10 years old) and three middle-aged adults (three males and two females) from Putre, Chile. Participants from Tacna, Peru, were two vendors (one female and one male) working at the main food market of the city. Interviews and observations were conducted at sites normally used by the participants (street, market place, school, and hotel).

Oral interviews were conducted with all participants in order to learn their direct or indirect knowledge about Llayta (origin, physical description, uses, places where Llayta grows and is sold, its quality as food). In addition, children were also asked to draw representations of Llayta in order to evaluate how close their depictions were from the real subject.

\section{Results}

\subsection{The Vocable Llayta: Alternative Names and Their Meaning}

Llayta is the Aymara name that refers to colonies of a cyanobacterium that grows in the Andes highlands and is consumed by rural and urban communities in South America (Figures 1 and 2). Alternative names for Llayta can be found in several languages: Spanish, Quechua, Kunza and Mapudungun (Table 1). The variety of names for the vocable Llayta stresses the cultural and anthropological diversity of representations associated with this feeding practice. 
Table 1. The Llayta vocable: alternative names, their ethnic origins and meaning.

\begin{tabular}{|c|c|c|c|}
\hline Name & Language & Comments & Reference \\
\hline $\begin{array}{l}\text { Cushuro } \\
\text { Llullucha } \\
\text { Murmuta } \\
\text { Crespito } \\
\text { Yrurupa }\end{array}$ & & The author did not indicate the language of origin of the words. & [12] \\
\hline $\begin{array}{l}\text { Chuncoro } \\
\text { Murmunta }\end{array}$ & Aymara & $\begin{array}{l}\text { "Vna yerua negra de comer, frutilla fe llama Chun-coro,o Murmunta" } \\
\text { (Edible black herb called Chuncoro or murmuta) }\end{array}$ & [3] \\
\hline $\begin{array}{l}\text { Murmunta } \\
\text { Chuncuru }\end{array}$ & Aymara & $\begin{array}{c}\text { "(Prunus capulí Cav.) Cerezo. La infusión de las hojas de esta planta se } \\
\text { usa como laxante. Sus frutos en Aymara se llaman". } \\
\text { (The leaves infusion is used as a laxative. Their fruit are named } \\
\text { in Aymara) }\end{array}$ & [22] \\
\hline Cerezo & Aymara & “s. Cerezo. Plumas coloridas (10)” (Colored feathers) & [23] \\
\hline $\begin{array}{l}\text { Quchayuyo } \\
\text { Murmunta }\end{array}$ & Aymara & $\begin{array}{l}\text { "Bot. Cerezo. 2. Plumas coloridas, en Bolivia. Bot. Cochayuyo de agua } \\
\text { dulce y del mar (p.e. alga comestible). } \\
\text { Vte. QUCHAYUYU, MURMUNTA" } \\
\text { (Colored feathers in Bolivia. Bot. Macroalga from freshwater and sea } \\
\text { water) (edible alga)) }\end{array}$ & [24] \\
\hline Chungullu & Quechua & $\begin{array}{c}\text { "una cianobacteria comestible, se encuentra en riachuelos y lagunitas } \\
\text { del bofedal ubicado entre Isluga y Colchane, en las cercanías de la } \\
\text { frontera entre Bolivia y la Región de Tarapacá en Chile". } \\
\text { (An edible cyanobacterium, found in small rivers and lakes of wetlands } \\
\text { located between Isluga and Colchane, near the border between Bolivia } \\
\text { and the Tarapacá Region in Chile) }\end{array}$ & [7] \\
\hline $\begin{array}{l}\text { Murmunta, } \\
\text { Chuncuro }\end{array}$ & $\begin{array}{l}\text { Aymara } \\
\text { Quechua }\end{array}$ & $\begin{array}{c}\text { “. . , probablemente derivado de su morfología, hábitat y uso. } \\
\text { En Aymara: hierba de las ciénagas como granillos negros". } \\
\text { (... derived probably from its morphology, habitat and use. } \\
\text { In Aymara: black grain herb from wetlands) }\end{array}$ & [7] \\
\hline $\begin{array}{l}\text { Luche } \\
\text { (lucha) }\end{array}$ & Mapuche & $\begin{array}{c}\text { “..., es un símil de una alga roja, marina y comestible". } \\
(\ldots, \text { is like a marine edible red alga) }\end{array}$ & [7] \\
\hline Yullucha & Aymara & $\begin{array}{l}\text { "De llullu para referirse a formas vegetales que empiezan a } \\
\text { desarrollarse o se pasman". } \\
\text { (From llullu, to refer to plants starting or have stopped their growth). }\end{array}$ & [8] \\
\hline $\begin{array}{l}\text { Tchuckula } \\
\text { Chucula }\end{array}$ & Kunza & $\begin{array}{l}\text { "Nombre atacameño de la cianobacteria comestible Nostoc. } \\
\text { Planta acuática que hay en la cordillera". } \\
\text { (Name given by the Atacameños people to the edible cyanobacterium } \\
\text { Nostoc. Aquatic plant found in the Andes Range). }\end{array}$ & [8] \\
\hline Yoyo & $\begin{array}{l}\text { Aymara } \\
\text { Quechua }\end{array}$ & $\begin{array}{l}\text { "Cianobacterias del género Nostoc" } \\
\text { (cianobacteria from the genus Nostoc). }\end{array}$ & [9] \\
\hline $\begin{array}{l}\text { Chungulle, } \\
\text { chungullo }\end{array}$ & Quechua & $\begin{array}{l}\text { "Cianobacteria acuática de bofedales, procedentes de Chela. Se usa } \\
\text { para la comida (caldo con papas chuño). } \\
\text { Se indicó que "hay uno que se come, es especial. Se lava y se seca". } \\
\text { (Aquatic cyanobacterium from Chela wetland. It is used as food, in } \\
\text { soups with potatoes. It was mentioned that there is an edible one which } \\
\text { is special. It is washed and dried). }\end{array}$ & [9] \\
\hline Luche & Mapuche & $\begin{array}{l}\text { "Símil de un alga roja comestible para designar a } \\
\text { un alga verde-azulada de agua dulce, también comestible (Nostoc)". } \\
\text { (Similar to an edible red alga, it is (Used to indicate an edible, } \\
\text { freshwater blue-green alga, (Nostoc)). }\end{array}$ & [9] \\
\hline Yoyo & Aymara & $\begin{array}{l}\text { "Nombre de la cianobacteria Nostoc en Ollagüe, posiblemente } \\
\text { aludiendo a su carácter comestible. Planta acuática comestible". } \\
\text { (Name given in Ollagüe to the cyanobacterium Nostoc, } \\
\text { possibly due to its edibility). }\end{array}$ & [9] \\
\hline
\end{tabular}

\subsection{How Much People Know about Llayta}

All participants were interviewed to assess the type and level of knowledge they have on Llayta. Table 2 provides extracts of the answers given by 10 participants ( 7 adults and 3 students). Only 8 of the 19 participants had some perception about Llayta; the others (58\%) lack any knowledge about it. 
The extracts in Table 2 corroborate that 7 participants have had personal experience of Llayta, i.e., direct knowledge. Only one teacher expressed indirect knowledge about Llayta since the information was second-hand (Table 2). Compared with adult participants, the oral expression of knowledge used by the fourth-grade students from Putre to refer to Llayta were few or absent. When asked to draw an image of Llayta, 11 out of 12 students were willing to participate and their drawings were far from a correct depiction of the colonies. As an exception, one student emphasized that his mother used to cook Llayta and her drawing was the closest image to it. Another student said: "no, yo no" (No, I do not (know Llayta)). A third student asked: " ¿Esa es la Llayta? (Is this Llayta?), referring to a drawing made by another student. Table 2 is a compilation of the representations of Llayta.

Table 2. Transcripts of interviews conducted to adult and students participants about their knowledge on Llayta.

\begin{tabular}{|c|c|}
\hline Informant & Type of Knowledge about Llayta \\
\hline $\begin{array}{l}\text { Saleswoman at the } \\
\text { food market, Tacna, } \\
\text { Peru. }\end{array}$ & $\begin{array}{l}\text { "Ahí huapé súcuros; de Súcuro se trae; de súcuro de ahí al fondo pues; ahí arriba de Puno. Otros } \\
\text { caballeros traen y ahí compramos; para picante. Si, picante prepara rico ahí comen". } \\
\text { (There, huapé súcuros; it is brought from Sucuro; down there; there, above Puno. Other people bring it } \\
\text { and we buy it to make "picante"-A local dish; yes, a tasty picante is prepared up there). }\end{array}$ \\
\hline $\begin{array}{l}\text { Professional cook, } \\
\text { Chile. }\end{array}$ & $\begin{array}{l}\text { "Para el consumo lo comemos eh; la Llayta es un tipo de alga de mar, de agua dulce y de mar también hay. } \\
\text { Lo traen y lo hacen secar, y seco lo venden en los negocios; para cocinarlo se la remoja. Los peruanos los } \\
\text { comen la Llayta y el cochayuyo. De la altura, de Puno, de Juliaca, bofedales eso está en la altura, en agua } \\
\text { dulce en los ríos crece por ahí, bueno acá en la frontera con Perú, tripartito, Visviri, ahí también crece". } \\
\text { (We eat it for consumption, eh!; Llayta is a kind of marine alga; it is from freshwater and also marine. } \\
\text { They bring it, dry it and sell it dried; they soak it before cooking. Peruvians eat Llayta and cochayuyo. } \\
\text { From the highlands, from Puno, from Juliaca, from wetlands, which are in the highlands, in freshwater } \\
\text { rivers, it grows around; right here, at the three parties' border, it also grows at Visviri). }\end{array}$ \\
\hline $\begin{array}{l}\text { Middle age woman, } \\
\text { Putre, Chile. }\end{array}$ & 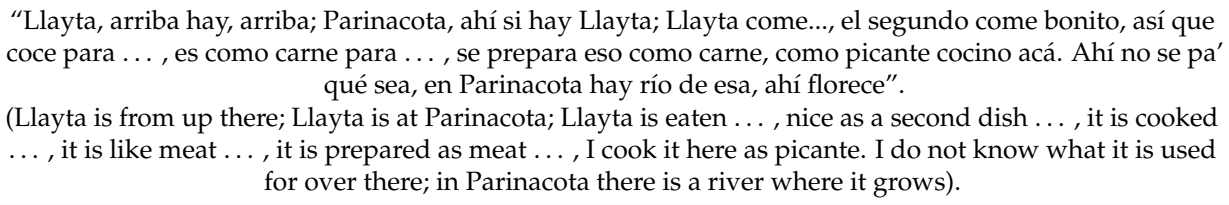 \\
\hline $\begin{array}{l}\text { Director, school at } \\
\quad \text { Putre, Chile. }\end{array}$ & $\begin{array}{l}\text { "La Llayta es de por acá también. La Llayta se usa para el picante. La he comido no más, pero no sé qué } \\
\text { me ha hecho; acá hacen mucho picante de pata con guata y Llayta. Hay en las lagunas, en Caqueña, en } \\
\text { Tacna y aquí arriba Caquena". } \\
\text { (Llayta is from here too. Llayta is used in picante. I have only eaten it; I do not know the effects on me; } \\
\text { people right here prepares a lot of picante with meat and Llayta. There are some ponds, in Casqueña, in } \\
\text { Tacna and up here in Caquena). }\end{array}$ \\
\hline $\begin{array}{l}\text { Student } 1 \text {, at school } \\
\text { in Putre, Chile. }\end{array}$ & $\begin{array}{l}\text { "Ah! yo sí, porque mi mamá cocina. En Caquena". } \\
\text { (Mm! I do, since my mother cooks it. At Caquena ... ). }\end{array}$ \\
\hline \multicolumn{2}{|r|}{ INDIRECT KNOWLEDGE: } \\
\hline $\begin{array}{l}\text { Teacher } 2 \text { at school } \\
\text { in Putre, Chile. }\end{array}$ & $\begin{array}{l}\text { "Eh ... Yo no las he visto pero sí me han dicho que ahí en la laguna está la Llayta" pero de verla no. } \\
\text { En Caqueña en Tacna y aquí arriba Caquena". } \\
\text { (Eh ... , I have not seen it, but I have been told that Llayta is at the pond, but I have not seen it. } \\
\text { At Caquena, in Tacna and up here in Caquena). }\end{array}$ \\
\hline \multicolumn{2}{|r|}{ WITHOUT KNOWLEDGE: } \\
\hline $\begin{array}{l}\text { Student 2, at school } \\
\text { in Putre, Chile. }\end{array}$ & “No, yo no". (No, I do not ... know Llayta). \\
\hline $\begin{array}{l}\text { Student 3, at school } \\
\text { in Putre, Chile. }\end{array}$ & “¿esa es la Llayta?” (Is that Llayta?) \\
\hline
\end{tabular}




\subsection{Fields of Representations for Llayta}

Table 2 shows the extracts from the ethnographic registries. These are the descriptions and references that sustain the field of representation of Llayta for 7 adult participants, which can be organized in the following 3 semantic fields:

\subsubsection{What is it?}

"Es un musgo que se trae de Caquena"; "es un musgo parecido al cochayuyo, es la misma que venden en el agro". "Ésta es nacional"; "la Llayta es un tipo de alga de mar, de agua dulce y de mar también hay".

"It is a moss brought from Caquena"; "it is a moss similar to cochayuyo (seaweed), it is the same that is sold at the market", "This is national"; "Llayta is a kind of marine alga; from freshwater and also from the sea".

\subsubsection{Where is it from?}

"De súcuro se trae", "De súcuro de ahí al fondo pues"; "Ahí arriba de Puno"; "ésta es de río"; "en Parinacota hay río de esa, ahí florece"; "la Llayta es de por acá también"; "Hay en las lagunas, en Caqueña en Tacna y aquí arriba Caquena"; "de la altura, de Puno, de Juliaca, bofedales eso está en la altura, en agua dulce en los ríos crece por ahí, bueno acá en la frontera con Perú, tripartito, Visviri, ahí también crece"; "Llayta, arriba hay, arriba"; "Parinacota, ahí si hay Llayta"; "la Llayta es de por acá también"; “en Caquena"; "Eh ... Yo no las he visto pero sí me han dicho que ahí en la laguna está la Llayta, pero de verla no"; "en Caquena".

"It is brought from Sucuro"; "from Sucuro, back there"; "from Puno, up there"; "this is from a river"; "at Parinacota, there is a river where it blooms"; "Llayta is from here too"; "it is from ponds, at Caquena, in Tacna, and up here in Caquena"; "from highlands, at Puno, Juliaca, wetlands, this is at the highlands, it grows in freshwater rivers, well, here at the border with Peru, Visviri, where it also grows; "Llayta, it is up there, up high"; "Llayta is at Parinacota, for sure"; "Llayta is from here too"; "at Caquena"; "Eh ... , I have not seen it but I was told that over there at the pond, there is Llayta, but I have not seen it"; "at Caquena".

\subsubsection{What is it for?}

"Para picante"; "si picante prepara rico ahí comen"; "los peruanos los comen la Llayta y el cochayuyo"; "Llayta come... el segundo come bonito, así que coce para ... es como carne para ... se prepara eso"; "como carne, como picante cocino acá"; "la Llayta se usa para el picante"; "la he comido no más, pero no sé qué me ha hecho"; "¡no! y los picantes de guatita”; "ahí le ponen la Llayta ... "; "lo traen y lo hacen secar, y seco lo venden en los negocios para cocinarlo se la remoja"; "ah yo sí, porque mi mamá cocina".

"For making picante dish"; "yes, picante dish is good, they eat it"; "Peruvian people eat Llayta and cochayuyo"; "Llayta is for consumption ..., so you cook it . . , it is like meat ... ; like meat, like picante I cook it here"; "Llayta is used for picante"; "I have eaten it but I do not know how to prepare it"; "it is brought here, it is dried and it is sold dry to restaurants"; "it is soaked before cooking"; "yes I know it, my mother cooks it".

When asked for places where Llayta can be found, one informant from Tacna, Peru, used the vocable "chuncuru" (an Aymara synonym for Llayta) instead of using "Sucuru", the right geographic site to where Llayta can be found. This mistake can be explained by the phonetic similarity between both words. 


\section{Discussion}

\subsection{Microethnographic Aspects}

The ethnographic goal of this study was to document the anthropological and cultural tensions found in the social representations of the Llayta feeding practice and relate them to the knowledge and value given by the communities to Andean algae.

Ethnographic registries allow the collection of evidence and social representations from people on a particular subject, to discover what people think, believe, and know about their surroundings, and understand how people see it and fit it in their particular interpretations of realities $[21,25,26]$. The knowledge people may have on a particular natural situation is a good example of where social representations can be collected and interpreted from social and cultural perspectives [26]. Also, descriptions and references from participants are essential in the field of representation for an event of ethnographic interest [22].

In the study of the Llayta feeding practice, the ethnographic registry can be supported by anthropological, socio-cultural, and nutritional referents [20]. The first two provide information on the meaning(s) of the term Llayta, the identification of sites where Llayta grows naturally, and where it is commercialized and consumed.

Our results indicated that nearly $40 \%$ of the participants declared they knew Llayta and described it as a moss or an alga, without clarifying whether it grows in fresh water or seawater (Table 2). They also provide names for the sites of origin of Llayta: Parinacota, Putre, Caquena and Visviri in Chile, and Sucuro, Juliaca and Puno in Peru (Table 2, Figure 2). The participants knew that Llayta is used to prepare "picante", a typical dish from rural areas in the Andes; however, they were unaware of its nutritional properties. All fourth-grade students from Putre did not know Llayta (11 out of 12 students; $58 \%$ of the participants of this study).

It is of considerable concern to confirm that a large proportion of the participants, all young people, did not know Llayta. This apparent loss may be explained by considering the impact of new technologies on rural life, cultural changes and migration from rural regions into urban centers, as described for the Aymara people in northern Chile [24,27].

The cultural and anthropological tensions observed in this study stemmed from a lack of knowledge on the following subjects: (a) conceptual limitations to explain what is an Andean alga or a microalga; (b) geographic locations where Llayta can be found and commercialized; (c) weak descriptions to explain how Llayta is cooked; and (d) the benefits obtained from its consumption. Also, this low or absence of knowledge on Llayta can be explained by how people perceive and relate to the world around them and, most stressfully, by a probable extinction of an Andean cultural practice. The massive ignorance about Llayta found in discussions with children in Putre is a clear example of it.

These anthropological tensions are indication of a paucity of information on Llayta. There is therefore an urgent need to educate people about all the cultural and nutritional knowledge accumulated on Llayta, so that it can be properly valued as a nutritional foodstuff.

\subsection{Biochemical Characterization of Llayta}

Llayta consumption is a traditional practice whose future revitalization can be supported by ethnographic information and evidence on the nutritional quality of Llayta [4].

The first biochemical evaluation of colonies of Nostoc cells from Peruvian wetlands were published by Aldave-Pajares [16,17]. Later, Gómez-Silva et al. [18] registered the proximal composition of Llayta colonies sold and consumed in Chilean territory, and also for the biomass from the isolated Llayta cyanobacterium. Both studies are in agreement on the total protein $(30-35 \% w / w)$ and carbohydrate $(50-60 \% w / w)$ content of the Andean Nostoc biomasses. More recently, it was informed that $60 \%$ of Llayta amino acids can be classified as indispensable; total lipids accounted for $2 \%$ of the biomass dry weight; and $32 \%$ of total fatty acids were polyunsaturated fatty acids, Vitamin E content was $4.3 \mathrm{mg} \% w / w$, total polyphenols was $64 \mathrm{mg}$ (as equivalent to gallic acid), with an antioxidant 
activity of $17.4 \mu$ moles (as equivalent to Trolox), and total fiber content was $56 \%$ of dry weight [4]. Galetovic et al. [4] inferred that Llayta biomass is a nutritious dietary ingredient.

One reason for the need for safety assessments of foods and food ingredients based on microalgae and cyanobacteria biomasses to protect public health is the potential presence of cyanobacterial toxins active at low doses (e.g., microcystin and nodularin). In particular, Arthrospira platensis (Spirulina) is considered a safe food based on centuries of human consumption [23]. Comparatively, some species of the Nostoc genus have toxic members that synthesize microcystine-like cyanotoxin [28]. However, the genome of the colony-forming Nostoc strain isolated from the Llayta biomass did not show the presence of $m y c E$, a key gene in the microcystine biosynthetic pathway, rendering it as a non-toxic Nostoc strain $[4,28]$. In addition, the absence of epidemiological records associated with Llayta consumption diminishes but does not remove the potential presence of toxic secondary metabolites in this cyanobacterial biomass [4].

\section{Conclusions}

Llayta consumption is a feeding practice with a know-how that has been transmitted through generations in the rural Andean world of South America, without untoward effects on human health. Nevertheless, this ancestral feeding legacy is being lost in young generations from northern Chile. New educational and anthropological strategies must be developed if there is interest in promoting the preservation and value of this traditional feeding practice and cultural legacy.

Llayta is a nutritious dietary ingredient for human consumption. This is supported by the absence of adverse epidemiological evidence, but also with interdisciplinary studies that complement ethnographic records with biochemical information.

Caution on the amount of Llayta consumed daily, based on its arsenic content, must be stressed. However, mass growth of the cyanobacterium isolated from Llayta under controlled conditions would provide arsenic-free biomass for the formulation of new food products. This biotechnological approach would revitalize the use of and add value to this ancestral food ingredient for the benefit of not only Andean communities, but also the whole population of South America and the world.

Author Contributions: Conceptualization, B.G.-S. and M.R.; Data curation, M.R. and R.L. Funding acquisition, B.G.-S. and A.G.; Investigation, A.G.; Methodology, M.R.; Supervision, B.G.-S. and A.G.; Validation, R.L.; Writing—original draft, B.G.-S. and M.R.; Writing—review and editing, B.G.-S.

Funding: This research was funded by Universidad de Antofagasta, Chile, grant number SI-5305, and CONICYT-CHILE, grant number CeBiB FB-0001.

Acknowledgments: The authors would like to thank Celedonio Maron Chura, Biblioteca de Antropología Andina (Instituto para el Estudio de la Cultura y Tecnología Andina, Arica, Chile) for his useful comments.

Conflicts of Interest: The authors declare no conflict of interest. The funders had no role in the design of the study; in the collection, analyses, or interpretation of data; in the writing of the manuscript; or in the decision to publish the results.

\section{References}

1. Gómez-Silva, B. On the Limits Imposed to Life by the Hyperarid Atacama Desert in Northern Chile. In Astrobiology: Emergence, Search and Detection of Life; Basiuk, V.A., Ed.; American Scientific Publishers: Los Angeles, CA, USA, 2010; pp. 199-213.

2. Gómez-Silva, B. Lithobiontic life: Atacama rocks are well and alive. Anton Leeuwenhoek 2018, 111, $1333-1345$. [CrossRef] [PubMed]

3. Plaza, M.; Herrero, M.; Cifuentes, A.; Ibáñez, E. Innovative natural functional ingredients from microalgae. J. Agric. Food Chem. 2009, 57, 7159-7170. [CrossRef] [PubMed]

4. Galetovic, A.; Araya, J.E.; Gómez-Silva, B. Composición bioquímica y toxicidad de colonias comestibles de la cianobacteria andina Nostoc sp. Llayta. Rev. Chil. Nutr. 2017, 44, 360-370. [CrossRef] 
5. Villagrán, C.; Castro, V.; Sánchez, G.; Hinojosa, F.; Latorre, C. La tradición altiplánica: Estudio etnobotánico en los Andes de Iquique, primera región, Chile. Chungara 1999, 31, 81-186.

6. Villagrán, C.; Castro, V. Ciencia Indígena de Los Andes del Norte de Chile; Editorial Universitaria: Santiago, Chile, 2003.

7. Villagrán, C.; Romo, M.; Castro, V. Etnobotánica del sur de los Andes de la primera región de Chile: Un enlace entre las culturas altiplánicas y las de quebradas altas del Loa Superior. Chungara 2003, 35, 73-124. [CrossRef]

8. Pardo, O.; Pizarro, J.L. Chile: Plantas Alimentarias Prehispánicas; Ediciones Parina: Arica, Chile, 2013; ISBN 978-956-9120-02-2.

9. Gantar, M.; Svircev, Z. Microalgae and cyanobacteria: Food for the thought. J. Phycol. 2008, 44, $260-268$. [CrossRef] [PubMed]

10. Habib, M.; Ahsan, B.; Parvin, M.; Huntington, T.C.; Hasan, M.R. A Review on Culture, Production and Use of Spirulina as Food for Humans and Feeds for Domestic Animals and Fish. FAO Fisheries and Aquaculture. Circular No. 1034. 2008. Available online: http://www.fao.org/3/contents/b2d01d94-4707-54c1-9f6501f699fc6d07/i0424e00.htm (accessed on 19 October 2018).

11. Gao, K. Chinese studies on the edible blue-green alga, Nostoc flagelliforme: A review. J. Appl. Phycol. 1998, 10, 37-49. [CrossRef]

12. Qiu, B.; Liu, J.; Liu, Z.; Liu, S. distribution and Ecology of the edible cyanobacterium Ge-Xian-Mi (Nostoc) in rice fields of Hefeng County in China. J. Appl. Phycol. 2002, 14, 423-429. [CrossRef]

13. Bertonio, L. Vocabulario de la Lengua Aymara. Colección Biblioteca Nacional de Chile: Impreso en la Compañía de Jesús, Perú. Electronic Document. 1612. Available online: http:/ / www.memoriachilena.cl/ 602/w3-article-8656.html (accessed on 19 October 2018).

14. Mannheim, B. Poetic form in Guaman Poma's Wariqsa Arawi. Amerindian 1986, 11, 41-67.

15. Lagerheim, M.G. La Yuyucha. La Nuova Notarisia 3:1376-1377. 1892. Available online: https://archive.org/ stream/lanotaristacomme7293levi/lanotarisiacomme7293levi_djvu.txt (accessed on 29 November 2018).

16. Aldave-Pajares, A. Cuschuro, algas azul-verde utilizadas como alimento en la región altoandina peruana. Soc. Bot. Libertad 1969, 1, 9-22.

17. Aldave-Pajares, A. Algas andino peruanas como recurso hidrobiológico alimentario. Bol. Lima 1985, 7, 66-72.

18. Gómez-Silva, B.; Mendizabal, C.; Tapia, I.; Olivares, H. Microalgas del norte de Chile. IV. Composición química de Nostoc commune Llaita [Microalgae from northern Chile: Chemical composition of Nostoc commune Llaita]. Rev. Invest. Sci. Tecnol. 1994, 43, 19-25.

19. FAO. Food Security \& Nutrition around the World. 2018. Available online: http://www.fao.org/state-offood-security-nutrition/en/ (accessed on 29 October 2018).

20. Pereira de Sá, C. The Central Nucleus Approach to Social Representations. Electronic Document. 1996. Available online: http:/ /www.lse.ac.uk/methodology/pdf/QualPapers/CELSO-Core-periphery.pdf (accessed on 29 November 2018).

21. Lam, M.R.; Gómez, W.C.; Vega, M.B.; Peña, R.A. Representaciones del monumento natural La Portada de Antofagasta. Zona Próxima 2012, 17, 58-75.

22. Restrepo, B. Investigación en educación. In Especialización en Teoría, Métodos y Técnicas de Investigación Social; ARFO Editores e Impresores Ltda.: Bogotá, Colombia, 2002.

23. Banchs, M.A. Concepto de representaciones sociales: Análisis comparativo. Rev. Costarric. Psicol. 1986, 5, $27-40$.

24. Jodelet, D. La representación social: Fenómenos, concepto y teoría. In Psicología Social II. Pensamiento y Vida Social; Moscovici, S., Ed.; Paidós: Barcelona, Spain, 1984.

25. Niccolai, A.; Bagagli, E.; Biondi, N.; Rodolfi, L.; Cinci, L.; Luceri, C.; Tredici, M.R. In vitro toxicity of microalgal and cyanobacterial strains of interest as food source. J. Appl. Phycol. 2017, 29, 199-209. [CrossRef]

26. González, H.; Gundermann, H.; Rojas, R. Diagnóstico y Estrategia de Desarrollo Campesino en la I Región de Tarapacá; Serie Documentos de Trabajo; Taller de Estudios Andinos; Corporación Norte Grande, Ed.; Impresos Publicitarios: Arica, Chile, 1991; 246p. 
27. Carrasco-Gutiérrez, A.M.; González-Cortez, H. Movilidad poblacional y procesos de articulación rural urbano entre los Aymara del norte de Chile. Si Somos Americanos 2014, 14, 217-231. [CrossRef]

28. Rantala, A.; Rajaniemi-Wacklin, P.; Lyra, C.; Lepistö, L.; Rintala, J.; Mankiewick-Boczek, J.; Sivonen, K. Detection of microcystin-producing cyanobacteria in Finnish lakes with genus-specific microcystin synthetase gene E (mcyE) PCR and associations with environmental factors. Appl. Environ. Microbiol. 2006, 72, 6101-6110. [CrossRef] [PubMed] 